\title{
Faktor-Faktor Kepatuhan Minum Obat pada Penderita Malaria Vivax di Puskesmas Hanura Kabupaten Pesawaran
}

\author{
Indah Dian Shafira, Inocentia Gita Krisanti \\ Fakultas Kedokteran Universitas Lampung
}

\begin{abstract}
Abstrak
Malaria adalah penyakit menular yang disebabkan Plasmodium. Pada tahun 2017, kasus malaria di dunia mencapai 216 juta kasus. Lampung merupakan salah satu provinsi dengan kejadian malaria yang masih cukup tinggi dengan Kabupaten Pesawaran sebagai daerah dengan kasus terbanyak, khususnya pada Puskesmas Hanura. Tujuan penelitian ini yaitu identifikasi faktor-faktor yang mempengaruhi kepatuhan minum obat pada penderita malaria vivax di wilayah kerja Puskesmas Hanura. Penelitian ini merupakan penelitian analitik kuantitatif dengan desain penelitian cross sectional. Sampel adalah penderita malaria vivax selama kurun waktu enam bulan terakhir yaitu April - September 2019. Didapatkan proporsi tinggi penderita malaria vivax tidak patuh dalam minum obat yaitu sebesar 53,4\%. Dimana perempuan memiliki kepatuhan minum obat yang lebih tinggi daripada laki-laki. Sebesar $51,1 \%$ pasien berusia $\geq 17$ tahun memiliki kepatuhan yang tinggi daripada usia $<17$ tahun. Hasil penelitian ini menunjukkan bahwa tidak adanya hubungan yang bermakna antara jenis kelamin, usia, dan pengalaman menderita malaria sebelumnya dengan kepatuhan minum obat.
\end{abstract}

Kata Kunci :Malaria vivax, kepatuhan, pengobatan

\section{Factors Affecting Malaria Vivax Patients' Drug Adherence in Hanura Health Center, Pesawaran District}

\begin{abstract}
Malaria is an infectious disease caused by Plasmodium. In 2017, malaria cases in the world reached 216 million cases. Lampung is one of the provinces with a relatively high incidence of malaria with Pesawaran District as the area with the most cases, especially at the Hanura Health Center. Therefore, it is important to identify factors that influence medication adherence in patients with vivax malaria in the work area of the Hanura Health Center. This research is a quantitative analytic study with cross sectional research design. Samples were malaria vivax patients during the last six months, namely April - September 2019. From the research we obtained a high proportion of malaria vivax patients who are not compliant in taking medication that is equal to $53.4 \%$. Where women have higher medication adherence than men. As many as $51.1 \%$ aged $\geq 17$ years have higher adherence than age $<17$ years. The results of this study found that there was no significant relationship between sex, age and previous experience of suffering from malaria with adherence to taking medication.
\end{abstract}

Keywords : Malaria vivax, adherence, medication

Korespondensi: Indah Dian Shafira, Prodi Pendidikan Dokter, Fakultas Kedokteran, Universitas Lampung, Jalan Ir. Soemantri Brojonegoro No. 1 Gedong Meneng, Kedaton, Bandar Lampung, mobile 081288564757,e-mail indahdianshafira@yahoo.com 


\section{Pendahuluan}

Malaria adalah penyakit menular yang disebabkan Plasmodium, yaitu makhluk hidup bersel satu yang termasuk dalam kelompok Protozoa. Malaria ditularkan melalui gigitan nyamuk Anopheles betina yang mengandung Plasmodium di dalamnya. Lima spesies Plasmodium penyebab malaria pada manusia yaitu Plasmodium falciparum,Plasmodium vivax, Plasmodium malariae, Plasmodium ovale, dan Plasmodium knowlesi (Singh, 2013).

Gejala-gejala penyakit malaria dipengaruhi oleh daya tahan tubuh penderita, jenis Plasmodium, serta jumlah parasit yang menginfeksi. Umumnya manifestasi klinis yang disebabkan Plasmodium falciparum lebih berat dan lebih akut dibandingkan dengan jenis Plasmodium yang lain, sedangkan gejala yang disebabkan oleh Plasmodium malariae dan Plasmodium ovale adalah yang paling ringan. Gambaran khas dari penyakit malaria ialah adanya demam yang periodik, splenomegali, dan anemia (Arsin, 2012).

Pada tahun 2017, kasus malaria di dunia mencapai 216 juta kasus. Di daerah Afrika kasus ini mencapai 90\%. Maka PBB memasukkan malaria bersama AIDS dan tuberkulosis ke dalam SDGs (Sustainable Development Goals). Targetnya adalah menurunkan mortalitas dan morbiditas malaria lebih dari 90\% pada tahun 2030 (WHO, 2015).

Pemerintah Indonesia juga masih memandang malaria sebagai ancaman terhadap status kesehatan masyarakat terutama pada rakyat yang hidup di daerah terpencil. Hal ini tercermin dengan dikeluarkannya Peraturan Presiden Nomor: 2 tahun 2015 tentang Rencana Pembangunan Jangka Menengah Naional tahun 2015 - 2019 dimana malaria termasuk penyakit prioritas yang perlu ditanggulangi (Kemenkes RI, 2017).

Lampung merupakan salah satu provinsi dengan kejadian malaria yang masih cukup tinggi. Kasus paling banyak terjadi di Kabupaten Pesawaran. Annual Parasite Incidence (API) atau Angka Parasit Malaria per 1.000 penduduk merupakan jumlah penderia positif malaria dibandingkan dengan jumlah penduduk berisiko terkena malaria di suatu wilayah. API malaria di Kabupaten Pesawaran pada tahun 2016 masih cukup tinggi yaitu 4,44. Angka tersebut masih jauh dari target API malaria nasional yaitu 0,85 per 1000 penduduk. Pada tahun 2016 ditemukan sebanyak 1.915 kasus di Kabupaten Pesawaran (Dinkes Pesawaran, 2017). Persebaran kasus malaria berdasarkan wilayah kerja puskesmas dapat dilihat pada gambar 1 .

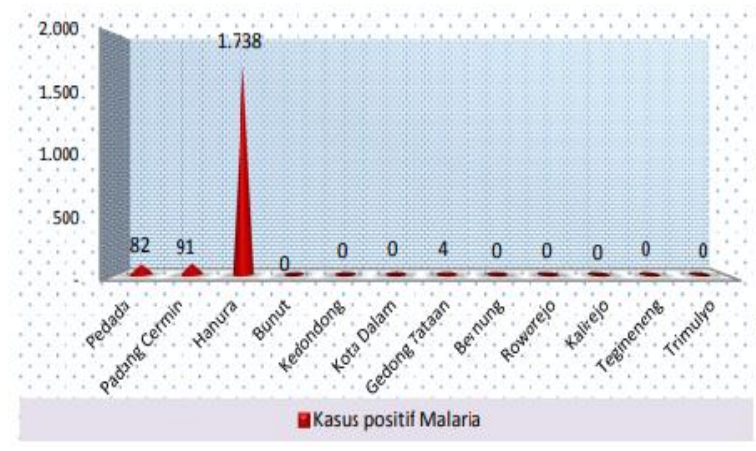

Sumber : Dinkes Pesawaran, 2017

Gambar 1. Persebaran kasus malaria di masingmasing puskesmas di Kabupaten Pesawaran tahun 2016

Kasus positif malaria terjadi di 4 wilayah yaitu Puskesmas Hanura (1.738 kasus), Puskesmas Padang Cermin (91 kasus), Puskesmas Pedada (82 kasus), dan Puskesmas Gedong Tataan (4 kasus). Tingginya kasus Malaria di wilayah tersebut dikarenakan kondisi alam yang mendukung sebagai tempat perindukan nyamuk seperti hutan, lagun dan tambak terlantar (Dinkes Pesawaran, 2017).

Pengobatan malaria vivax tanpa komplikasi saat ini menggunakan Artemisininbased Combination Therapy (ACT) ditambah primakuin. ACT diberikan selama 3 hari,

sedangkan primakuin diberikan selama 14 hari dengan dosis $0,25 \mathrm{mg} / \mathrm{kgBB}$. Primakuin tidak boleh diberikan pada bayi usia <6 bulan dan wanita hamil.Pengobatan kasus malaria vivaxrelaps (kambuh) diberikan dengan regimen ACT yang sama, tetapi dosis Primakuin ditingkatkan menjadi 0,5 $\mathrm{mg} / \mathrm{kgBB} / \mathrm{hari}$ (Kemenkes RI, 2017).

Salah satu tantangan terbesar dalam upaya pengobatan malaria di Indonesia adalah terjadinya kekambuhan atau relaps. Relaps pada malaria dibedakan atas rekurensi dan rekrudesensi. Rekurensi adalah kekambuhan malaria jenis Plasmodium vivax dan Plasmodium ovale yang disebabkan adanya fase hipnozoit yang dorman dalam sel hati, sehingga memungkinkan suatu saat penderita mengalami serangan malaria sekunder. Pada Plasmodium falsiparum dan Plasmodium malariae tidak ada fase hipnozoit. Kemungkinan berulangnya serangan disebabkan pengobatan yang tidak sempurna. Kekambuhan malaria seperti ini disebut rekrudesensi (Fitriany, 2018).

Selain menyebabkan relaps, pengobatan malaria yang tidak sempurna juga 
mengakibatkan permasalahan lain yaitu resistensi obat. Sejak tahun 1990 dilaporkan telah terjadi resistensi parasit Plasmodium falsiparum terhadap klorokuin di seluruh provinsi di Indonesia. Selain itu dilaporkan juga adanya kasus resistensi Plasmodium falsiparum terhadap Sulfadoksin-Pirimethamin (SP) di beberapa tempat di Indonesia. Keadaan seperti ini dapat meningkatkan morbiditas dan mortalitas akibat penyakit malaria (Kemenkes RI, 2017).

Berdasarkan uraian di atas, dapat diketahui pentingnya menyelesaikan pengobatan hingga 14 hari bagi penderita malaria vivax. Hal ini dilakukan untuk mencegah terjadinya relaps maupun resistensi obat. Dalam penelitian ini akan diidentifikasi faktor-faktor apa saja yang mempengaruhi kepatuhan minum obat pada penderita malaria vivax di wilayah kerja Puskesmas Hanura, Kabupaten Pesawaran, Provinsi Lampung. Diharapkan informasi ini dapat digunakan untuk merencanakan tindakan intervensi yang tepat untuk mengatasi masalah pengobatan malaria di masa yang akan datang.

\section{Metode}

Penelitian ini merupakan penelitian analitik kuantitatif dengan desain penelitian cross sectional. Sampel adalah penderita malaria vivax selama kurun waktu enam bulan terakhir yaitu April 2019 - September 2019. Kriteria sampel adalah penderita malaria vivax yang didiagnosis dengan Rapid Diagnostic Test (RDT) maupun pemeriksaan mikroskopis, dan bertempat tinggal di wilayah kerja Puskesmas Hanura. Sampel yang digunakan dalam penelitian ini sebanyak 30 penderita malaria vivax yang dipilih secara purposive sampling. Informasi tentang penderita malaria vivax didapatkan dari Puskesmas Hanura. Status kepatuhan penderita malaria dalam minum obat didapatkan dari kuesioner Morisky Medication Adherence Scale (MMAS). Data yang telah diperoleh kemudian dianalisis dengan program pengolah statistik.

Kriteria inklusi kelompok kasus penderita malaria vivax yang didiagnosis menggunakan Rapid Diagnostic Test (RDT) maupun pemeriksaan mikroskopis, penderita malaria vivax yang sedang menjalani pengobatan di Puskesmas Hanura, tinggal di wilayah kerja Puskesmas Hanura dan bersedia mengikuti penelitian dan menyetujui informed consent.

\section{Hasil}

Berdasarkan data pada tabel 1 menunjukkan bahwa proporsi terbesar penderita adalah perempuan $(73,3 \%)$. Hal ini sesuai dengan hasil penelitian Lario (2016) yang menyatakan bahwa perbedaan prevalensi malaria berdasarkan jenis kelamin berkaitan dengan variasi keterpaparan kepada gigitan nyamuk.

Tabel 1. Karakteristik Penderita Malaria Vivax di Wilayah Kerja Puskesmas Hanura

\begin{tabular}{|c|c|c|}
\hline Variabel & Jumlah & $\%$ \\
\hline \multicolumn{3}{|l|}{ Jenis kelamin } \\
\hline Laki-laki & 8 & $26,67 \%$ \\
\hline Perempuan & 22 & $73,3 \%$ \\
\hline \multicolumn{3}{|l|}{ Usia } \\
\hline 16 tahun ke bawah & 23 & $76,67 \%$ \\
\hline 17 tahun ke atas & 7 & $23,33 \%$ \\
\hline \multicolumn{3}{|l|}{ Riwayat malaria } \\
\hline Tidak & 6 & $20 \%$ \\
\hline $\mathrm{Ya}$ & 24 & $80 \%$ \\
\hline \multicolumn{3}{|l|}{ Tingkat Kepatuhan } \\
\hline Rendah & 14 & $46,6 \%$ \\
\hline Tinggi & 16 & $53,4 \%$ \\
\hline Tota & & $100 \%$ \\
\hline
\end{tabular}

Kejadian malaria berdasarkan tabel 1 di atas menunjukkan bahwa usia di bawah 17 tahun $(76,67 \%)$ lebih tinggi. Hal ini sesuai dengan pernyataan Gunawan (2000), bahwa perbedaan prevalensi menurut umur berkaitan dengan derajat kekebalan. Orang dewasa memiliki kekebalan lebih baik terhadap malaria daripada anak-anak.Selain itu anak-anak lebih banyak bermain di luar rumah pada waktu gelap yang memungkin adanya kontak dengan nyamuk (Arsin, 2012).

Sebanyak $80 \%$ dari responden menyatakan memiliki riwayat menderita malaria sebelumnya. Hal ini kerap terjadi di daerah endemis malaria. Riwayat malaria berulang ini dapat terjadi akibat relaps karena pengobatan yang tidak sesuai atau infeksi berulang.

Berdasarkan tingkat kepatuhan minum obat $53,4 \%$ penderita malaria vivax memiliki kepatuhan yang tinggi. Menurut CaseManagement Society of America atau CMSA (2006), beberapa faktor yang berpengaruh dalam kepatuhan pengobatan malaria yaitu faktor penderita, faktor sistem 
layanan kesehatan, faktor obat, dan faktor tenaga kesehatan.

Hubungan antara jenis kelamin dengan tingkat kepatuhan minum obat pada penderita malaria vivax dapat dilihat pada tabel 2. Hasil penelitian menunjukkan bahwa $62,5 \%$ penderita berjenis kelamin laki-laki memiliki tingkat kepatuhan rendah, sedangkan $59,1 \%$ penderita bejenis kelamin perempuan memiliki tingkat kepatuhan tinggi.

Tabel 2. Hubungan Jenis Kelamin dengan Tingkat Kepatuhan Minum Obat pada Penderita Malaria Vivax

\begin{tabular}{cccccc}
\hline $\begin{array}{c}\text { Jenis } \\
\text { Kelamin }\end{array}$ & \multicolumn{3}{c}{ Tingkat Kepatuhan } & \multirow{2}{p}{ - } \\
\cline { 2 - 5 } Tinggi & \% & Rendah & \% & value \\
\hline L & 3 & 37,5 & 5 & 62,5 & 0,155 \\
$\mathrm{P}$ & 13 & 59,1 & 9 & 40,9 &
\end{tabular}

Hubungan antara usia dengan tingkat kepatuhan minum obat pada penderita malaria vivax dapat dilihat pada tabel 3. Hasil penelitian menunjukkan bahwa 52,2\% penderita berusia di bawah 17 tahun memiliki tingkat kepatuhan rendah, sedangkan $51,1 \%$ penderita berusia 17 tahun ke atas memiliki tingkat kepatuhan tinggi.

Tabel 3. Hubungan Usia dengan Tingkat Kepatuhan Minum Obat pada Penderita Malaria Vivax

\begin{tabular}{cccccc}
\hline \multirow{2}{*}{ Usia } & \multicolumn{4}{c}{ Tingkat Kepatuhan } & \multirow{2}{*}{ Total } \\
\cline { 2 - 5 } & Tinggi & $\%$ & Rendah & $\%$ & \\
\hline$<17$ & 11 & 47,8 & 12 & 52,2 & 1,0 \\
$\geq 17$ & 4 & 51,1 & 3 & 42,9 & \\
$p$-value $: 1,0$ & & & & \\
\hline
\end{tabular}

Hubungan antara riwayat malaria sebelumnya dengan tingkat kepatuhan minum obat pada penderita malaria vivax dapat dilihat pada tabel 4. Hasil penelitian menunjukkan bahwa $50 \%$ penderita yang memiliki riwayat malaria sebelumnya memiliki tingkat kepatuhan tinggi.

Tabel 4. Hubungan Riwayat Malaria dengan Tingkat Kepatuhan Minum Obat pada Penderita Malaria Vivax

\begin{tabular}{cccccc}
\hline Riwayat & \multicolumn{4}{c}{ Tingkat Kepatuhan } & \multirow{2}{*}{ Total } \\
\cline { 2 - 5 } malaria & Tinggi & $\%$ & Rendah & \% & \\
\hline Tidak & 3 & 50 & 3 & 50 & 1,0 \\
Ya & 12 & 50 & 12 & 50 & \\
\hline
\end{tabular}

\section{Pembahasan}

Berdasarkan hasil uji statistik chi-square antara jenis kelamin dengan tingkat kepatuhan minum obat, didapatkan $p$-value sebesar 0,155. Hal ini berarti tidak terdapat hubungan yang bermakna antara jenis kelamin dengan tingkat kepatuhan minum obat. Persentase menunjukkan bahwa laki-laki cenderung memiliki tingkat kepatuhan minum obat yang rendah. Hal ini sesuai dengan hasil penelitian Wuryanto (2008) yang menyatakan hal serupa. Anggapan yang berkembang di masyarakat menyebutkan bahwa laki-laki cenderung tidak patuh karena beberapa alasan, seperti tidak telaten dan cenderung lupa minum obat akibat kesibukan bekerja.

Berdasarkan tabel 2 di atas, hubungan usia dengan tingkat kepatuhan minum obat, didapatkan $p$-value sebesar 0,155 . Hal ini berarti tidak terdapat hubungan yang bermakna antara usia dengan tingkat kepatuhan minum obat. Persentase menunjukkan bahwa penderita berusia di bawah 17 tahun cenderung memiliki tingkat kepatuhan yang tinggi. Hal ini sesuai dengan hasil penelitian Farouk (2016) yang menyatakan hal serupa. Penderita berusia di bawah 17 tahun cenderung memiliki kepatuhan tinggi akibat adanya PMO (pengawas minum obat) terutama dari pihak keluarga yang memastikan penderita minum obat secara teratur. Anak-anak biasanya diingatkan minum obat oleh orang tuanya yang ingin anaknya lekas sembuh.

Hubungan riwayat malaria dengan tingkat kepatuhan minum obat dalam uji statistik chi-square didapatkan $p$-value sebesar 1,00. Hal ini berarti tidak terdapat hubungan yang bermakna antara riwayat malaria dengan tingkat kepatuhan minum obat. Data menunjukkan $50 \%$ penderita dengan riwayat malaria sebelumnya memiliki tingkat kepatuhan yang rendah. Hal ini berarti pengalaman menderita malaria sebelumnya tidak mempengaruhi tingkat kepatuhan minum obat seseorang.

Faktor- faktor yang dapat mempengaruhi kepatuhan minum obat pada penderita malaria vivax yaitu faktor pasien, faktor sistem layanan kesehatan, faktor obat, dan faktor tenaga kesehatan. Faktor pasien meliputi usia, jenis kelamin, tingkat pendidikan, motivasi, serta pengetahuan penderita mengenai penyakit malaria serta pengobatan yang dijalani.

Faktor sistem layanan kesehatan meliputi tidak adanya asuransi kesehatan, biaya pengobatan yang mahal, serta tidak adanya akses ke fasilitas layanan kesehatan. Hal ini dapat mengakibatkan kepatuhan pengobatan yang rendah.

Faktor obat meliputi efek samping obat, banyaknya jumlah obat yang dikonsumsi, serta durasi pengobatan yang lama. Efek samping yang biasa timbul setelah mengkonsumsi obat 
anti malaria yaitu pusing, vertigo, diplopia, mual, muntah dan nyeri perut.

Faktor tenaga kesehatan meliputi hubungan yang buruk dengan tenaga kesehatan, kemampuan komunikasi yang buruk, serta tidak adanya dorongan positif dari tenaga kesehatan yang mengakibatkan tingkat kepatuhan minum obat yang rendah. Hal ini dapat diatasi dengan pelatihan tenaga kesehatan yang sesuai dengan kompetensinya masing-masing.

Proporsi tinggi penderita malaria vivax tidak patuh dalam minum obat yaitu sebesar $(53,4 \%)$. Didapatkan perempuan memiliki kepatuhan minum obat yang lebih tinggi daripada laki-laki. Sebesar $(51,1 \%)$ usia $\geq 17$ tahun memiliki kepatuhan yang tinggi daripada usia < 17 tahun. Banyaknya penderita yang mengalami riwayat malaria dinyatakan bahwa tidak ada hubungan yang bermakna dengan kepatuhan minum obat.

Usia dan jenis kelamin merupakan faktor yang mempengaruhi tingkat kepatuhan minum obat pada penderita malaria vivax, sehingga penjelasan cara minum obat yang benar kepada penderita malaria di puskesmas lebih ditingkatkan. Faktor yang tidak berhubungan dengan kepatuhan minum obat adalah riwayat penderita yang pernah terkena malaria. Hal ini berarti pengalaman penderita sebelumnya tidak mempengaruhi kepatuhan minum obat seseorang.

Simpulan yang dapat ditarik pada penelitian ini yaitu proporsi penderita malaria vivax yang tidak patuh minum obat sebesar $53,4 \%$, dimana perempuan memiliki kepatuhan minum obat yang lebih tinggi daripada lakilaki. Sebesar $51,1 \%$ pasien berusia $\geq 17$ tahun memiliki kepatuhan yang tinggi daripada usia < 17 tahun. Hasil penelitian ini menunjukkan bahwa tidak ada hubungan yang bermakna antara jenis kelamin, usia, dan pengalaman menderita malaria sebelumnya dengan kepatuhan minum obat.

\section{Daftar Pustaka}

Arsin, A.A. 2012. Malaria di Indonesia tinjauan aspek epidemiologi. Makassar : Masagena Press

Case Management Society of America. 2006 .Case Mangement Adherence Guidelines Version 2. USA: Case Management Society of America

Dinas Kesehatan Kabupaten Pesawaran. 2017. Profil kesehatan Kabupaten Pesawaran. Pesawaran : Dinas Kesehatan Kabupaten Pesawaran
Farouk, A. 2016. Analisis faktor-faktor yang berhubungan dengan kepatuhan pengobatan malaria di Kabupaten Sarolangun Provinsi Jambi tahun 2015. Jurnal Ilmiah Universitas Batanghari Jambi Vol 16(1)

Gunawan, S. 2000. Epidemiologi Malaria, dalam: Harijanto $P N, \quad$ Malaria: Epidemiologi, Manifestasi Klinis, dan Penanganan. Jakarta: EGC

Kementerian Kesehatan RI. 2017. Buku saku penatalaksanaan kasus malaria. Jakarta : Kementerian Kesehatan RI

Fitriany, J. dan Sabiq, A. 2018. Malaria. Jurnal Averrous Vol. 4(2)

Lario, J.S.C., Bidjuni, H., Onibala, F. 2016. Hubungan Karakteristik \& Perilaku Masyarakat dengan Kejadian Malaria di Rumah Sakit Sinar Kasih Tentana Kabupaten Poso, Provinsi Sulawesi Tengah. eJournal Keperawatan Vol. 4(1)

Singh, B. and Daneshvar, C. 2013. Human infections and detection of Plasmodium knowlesi. Clinical Microbiology Reviews. 26(2):165-84.

World Health Organization (WHO). 2015. Global technical strategy for malaria 2016-2030. Geneva : WHO

Wuryanto, M.A. 2008. Tingkat kepatuhan penderita malaria vivax dalam minum obat serta faktor yang mempengaruhinya. Jurnal Promosi 